\section{$1 \mathrm{H1030}$}

最小筋収縮系に見られる単一アクチンフィラメント のステップ状の動きとカ発生

○鈴木 団 ${ }^{1}$ 、藤田 英明 ${ }^{2}$ 、石渡 信一 ${ }^{1}$ ( 1 早大·理工・物理、 2 アイオワ大・医)

横紋筋筋原線維中にあって主にミオシンフィラメントの束からな るA帯と、一本のアクチンフィラメント間で発生する張力を計測す るような新しい実験系の開発を試みている。この系の特徴と利点は、 A 帯がグリセリン処理さ机たウサギ腸腰筋筋原線維から調製される ために、ミオシンフイラメントが本来の周期構造、立体構造を保って いること、そして力計測が生体内に準ずるイオン強度でも行える点に ある。このことは、生理的イオン强度ではミオシンヘッドがアクチン フィラメントから容易に解離してしまうために低イオン強度下での奏 験に制限されているin vitro 滑り運動系と対照的である。ローダミン ファロイジンで蛍光染色したアクチンフィラメントの全長とA带に 入り込んだ部分の長さは、フィラメントの蛍光像と $\mathrm{A}$ 帶の位相差像と から見積もった。力計測は、ゲルソリリを介してアクチンフィラメン トのB端 (後端)に結合した直径 $1 \ell \mathrm{m}$ のポリスチレンビーズを光 ピンセットで捕捉し、力発生に伴うビーズの変位を位相差像の解析か ら 10-200 $\mathrm{nm}$ (光ピンセットのバネ趸数が $(0.1 \mathrm{pN} / \mathrm{nm}$ なので $1-20 \mathrm{pN}$ ) の範井で求めることにより行った。

以上の方法により、収綰条件 $\left(100 \mathrm{mM} \mathrm{KCl} .2 \mathrm{mM}\right.$ free $\mathrm{Mg}^{2+} .2 \mathrm{mM}$ MgATP, 25mM Imidazole-HCl(pH7.4), 1mM EGTA. 0.5mg/ml BSA. 10mM DTT, ATP 再生系. 酸素除去酵素系) に扔けるクロスブリッジ

一個あたりの出す平均力を約 $0.4 \mathrm{pN}$ と見積もった。また、10 (あるい は5）ｎ１のステップ状の変位が、力発生時の定常状態、そしてさら に頙著には、ステップ状に負荷を加え、フイラメントが $\mathrm{A}$ 带から引の ぱり出されるときに観察された。この上うなステップは、硬值条件下 では見られないことから、力発生に共役したクロスブリッジの動き、 あるいは A 帯中のクロスブリッジの配列や、アクチンフィラメント の構造の周期性を反映している可能性がある。

M.Suzuki, H.Fujita and S.Ishiwata : Stepwise movement and force generation observed in an A-band motility assay system

\section{$1 \mathrm{H} 1100$}

\section{ATP アナログ存在下でのアクトミオシン滑り運動}

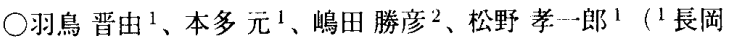
技科大.生物、2名市大・芸政)

ATPとATPアナログの混合溶液中に扔いて、ミオシンヘッド上で のアクチン䄉維の滑り運動を観察した。ADP存在下ではATP 濃度の 広い範囲にわたってアクチン䄉維の滑り速度が著しく減少した。それ に対して AMP-PNP 存在下でのアクチン䄉維の滑り速度は、ATPた けのときと比べてわずかに低下するにとどまった。ATPアナロクに よってヌクレオチドなしのミオシンへッドを隇少させても、滑り速度 の增加はみられず、ライゴール結合の負荷が速度を直接趛くしている とはいえない。さらにまた、ATP漂度が低いときには、ATPの消費に よってアクチン縺維の運動は短時間に急速に隇少するが、AMP-PNP 存在下では、比較的長時間にわたり運動を持続した。AMP-PNPによ り生じる弱い結合は滑り速度を増大させるより、ATP分解のエネル ギーを効率よく滑り運動に変換することに寄与する。

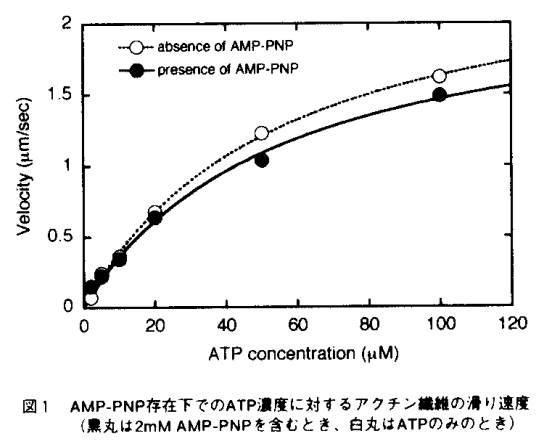

K. Hatori. H. Honda, K. Shimada, K. Matsuno: Sliding movement of actin filament on myosin heads in the presence of ATP analogue.

\section{$1 \mathrm{H} 1045$}

SH1 と SH2 を化学架橋した骨格筋ミオシンの急速凍 結ディープエッチレプリカ電子顕微鏡法による直接観 察と蛍光プローブを用いた解析

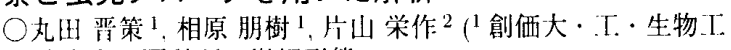
学. ${ }^{2}$ 東大·医科研・微細形態)

骨格筋ミオシンには、非常に反応性の高い二つのシステイン残基 SH1(707) と SH2(697)が存在しており、長さの異なる幾つかの二価 性試薬 (3-14 $\dot{\mathrm{A}}$ )で化学架橋されることから、これらの領域は極めて flexibleであることが示唆されている。また mucleotideの結合により 大きく構造変化を起こすことが示されており、エネルギー変換に重要 な役割をしていると考六ら机ている。我々は以前、ミオシン ATPase サイクルにおいて $\mathrm{M}^{* *}$-ADP-Pi state 模做するミオシン-ADP-フッ 化金属複命体が大きく折れ曲がるような構造をしていることを、急速 凍結ディープエッチレプリカ電子顕微镜法で值接観祭している。この 全体的な折れ曲がりは、SH1-SH2での局所的な構造変化が直接関与し て生じている叮能性が考えられる。そこでSH1とSH2を長さの買なる 3 つの架橋試薬 DTNB $(2 \dot{A}) 、$ F2DNB $(5 \dot{A}) 、$ pPDM $(12-13 \dot{A})$ で架 橋した骨格筋へビーメロミオシン (HMM)を調製して急速凍結ディー プエッチレブリカ電子顕微鏡法で観察した。架橋反応は $\mathrm{Ca}^{2+}$-ATPase 活性の阻害でモニタ一を行い、いずれの試薬においても HMMのSH1SH2が $90 \%$ 以上架橋されていることが確認された。DTNBで架橋さ れた HMMでは、架橋されていないHMM と比較して大半が大きく 折れ曲がった像として観察された。 pPDMと F2DNBで架橋された HMMに执いも一部折れ曲がったものが、観察されたがDTNBほ ど顥著ではなかった。またDTNBで架橋された HMMに結合した蛍 光プロープ prodanのスペクトルは $\mathrm{M}^{* *} \cdot \mathrm{ADP} \cdot \mathrm{Pi}$ state と同様に 4451111 へ蛍光極大が blue shift した蛍光スペクトルを示した。

S. Maruta, T. Aihara \& E. Katayama : Direct observation of skeletal muscle myosin chemically crosslinked at $\mathrm{SH} 1$ and $\mathrm{SH} 2$ and their analysis using fluorescent probe?

\section{$1 \mathrm{H} 1115$}

蛍光標識 ATP アナログ NBD-ATP と骨格筋ミオシ ンとの相互作用およびミオシン・NBD-ADP・フッ 化金属の形成

○水會 良明、石井 带紗美、梅木 伸久、丸田 晋策（創価大 $\mathrm{I}$. 生物 $\mathrm{T}$ 学

ミオシン ATPase サイクルにおいて、異なるステップを示すと考え られる幾つかのミオシン-ADP-フッ化金属複合体の形成のモニターと これらの複合体の構造の違いを調べるために、蛍光標識 ATPアナロ "゙ 2'(3')-[6-(N-(nitrobenz-2-oxa-1,3-diazol-4-yl)amino)hexanoic-ATP (NBD-ATP) を合成した。骨格筋ミオシン S1に対してNBD-ATPは regular ATP と同程度の $\mathrm{Mg}^{2+} . \mathrm{Ca}^{2+}, \mathrm{EDTA}\left(\mathrm{K}^{+}\right)$-ATPase 加水分解速 度を示した。またIn vitro motility assayにより regular ATPよりわず かに速い速度で、アクチンを滑走させることが観測された。NBD-ATP がミオシンに結合すると、その蛍光強度は約 $40 \%$ \%隇少し、加水分解 後、蛍光強度は回復した。この状態でリン酸アナログであるフッ化金 属 $\mathrm{AlF}_{4}$-と BeFnを加えると、再び蛍光強度が隇少が見られた。この 時の蛍光減少速度恃報告されている $\mathrm{S} 1-\mathrm{ADP}-\mathrm{AlF}_{4}{ }^{-}$と $\mathrm{S} 1-\mathrm{ADP}-\mathrm{BeF}_{11}$ 複合体の形成速度とよく一致しており、複合体の形成を NBD-ADP の蛍光強度の変化でモニターできることが示唆された。また活性シ ステイン SH2(697) を蛍光試薬 acrylodan (AD) で標識した AD-S1に NBD-ATPが結合すると NBD 基と AD 基の間で蛍光エネルギー移動 が起こることが観察された。現在、構造の違いを明らかにするために 各複合体の蛍光エネルギー移動の測定を試みている。
Y Mizukura, A. Ishii, N. Umeki \& S. Maruta : Interaction of fluorescent ATP analogue NBD-ATP with skeletal muscle myosin and formation of myosin-(NBD-ADP)-fluorometal complexes 